\title{
The Economic Performance of Hydropower Dams Supported by the World Bank Group, 1975-2015
}

\author{
Saule Baurzhan ${ }^{1}\left(\mathbb{D}\right.$, Glenn P. Jenkins ${ }^{2, *}$ and Godwin O. Olasehinde-Williams ${ }^{3}$ \\ 1 Department of Economics, Eastern Mediterranean University, Famagusta 99450, Turkey; \\ saule.baurzhan@gmail.com \\ 2 Department of Economics, Queen's University, Kingston, ON K7L 3N6, Canada \\ 3 School of Economics and Management, Nanchang University, Nanchang 330031, China; alanisey@gmail.com \\ * Correspondence: jenkins@econ.queensu.ca
}

Citation: Baurzhan, S.; Jenkins, G.P.; Olasehinde-Williams, G.O. The Economic Performance of Hydropower Dams Supported by the World Bank Group, 1975-2015. Energies 2021, 14, 2673. https:// doi.org/10.3390/en14092673

Academic Editor: Ferda Halicioglu

Received: 5 March 2021

Accepted: 27 April 2021

Published: 6 May 2021

Publisher's Note: MDPI stays neutral with regard to jurisdictional claims in published maps and institutional affiliations.

Copyright: (C) 2021 by the authors Licensee MDPI, Basel, Switzerland. This article is an open access article distributed under the terms and conditions of the Creative Commons Attribution (CC BY) license (https:// creativecommons.org/licenses/by/ $4.0 /)$.

\begin{abstract}
This paper assesses the economic benefits of 57 World Bank Group-sponsored hydropower dam plant investments. Hydropower dams are among the main sources for producing electricity and the largest renewable source for power generation throughout the world. Hydropower dams are often a lower-cost option for power generation in Clean Energy Transition for addressing global climate change. Despite its conspicuous aspects, constructing hydropower dams has been controversial. Considering the World Bank's long history as the largest hydropower development financier, this study investigates its performance in supporting hydropower dams. The outcomes of this study apply to the wider hydropower development community. Of the projects in this study, $70 \%$ experienced a cost overrun, and more than $80 \%$ of projects experienced time overruns, incurring potential additional costs as a result. Despite the high cost and time overruns, this hydropower portfolio of dams produced a present value of net economic benefits by 2016 of over half a trillion USD. Based on our findings, the evaluated hydropower portfolio helped avoid over a billion tonnes of $\mathrm{CO}_{2}$ for an estimated global environmental benefit valued at nearly USD 350 billion. The projects' additional environmental benefits raise the real rate of return from $15.4 \%$ to $17.3 \%$. The implication for hydropower developers is that the projects' assessment should consider cost and time overrun and factor them into the project-planning contingency scenarios. There is a considerable benefit for developing countries to exploit their hydropower resources if they can be developed according to industry practices and international standards. The case for developing hydropower may be stronger when considering its climate benefits. The net economic benefits of hydropower can be even higher if there is a greater effort to manage cost and time overruns.
\end{abstract}

Keywords: investment appraisal; carbon emissions; cost overrun; hydropower; dams; World Bank

\section{Introduction}

One component of a solution to the global energy challenge is the intensification of investment in hydropower projects that provide clean, reliable, and affordable energy [1]. Advocates of hydropower projects cite their numerous benefits, such as the reduction in fossil fuel consumption, provision of water for irrigation and other uses, flood control, and inland water transport. On the other hand, hydropower projects would almost certainly result in environmental challenges. Many studies have indicated, for example, that the proposed hydropower projects would cause significant changes in river hydrology, potentially jeopardizing local livelihoods and well-being by depleting capture fisheries, sediment, and nutrient flows [2-6]. However, a common challenge often faced by hydropower projects is the issue of cost and time overruns. A review of previous research on this subject provides clear evidence that a significant number of hydropower projects suffer from cost and time overruns [7-13].

Accurate projections of construction schedules and costs are crucial to the development of hydropower projects [14]. These construction time and cost projections are central 
elements in preparing construction and operation timetables and the financial arrangements associated with such projects [9]. Hence, construction cost and time overruns increase the probability of a loss of economic justification for executing hydropower projects. Cost and time overruns may also significantly affect the project owners' financing capacity and the electricity pricing policies in the place where the project is situated. Detailed investigation into the issues surrounding cost and time overruns can provide vital insight into inefficiencies associated with different stages in the evaluation and construction phases of hydropower projects [15]. Thus, the authors seek to determine how cost and time overruns affect the net economic benefits of a portfolio of 68 hydropower projects financed by the World Bank Group (WBG) between 1975 and 2015.

This study builds on Awojobi and Jenkins's earlier work [12], which examined the net economic benefits of 58 WBG-financed hydropower projects between 1975 and 2005. It is thus essential to evaluate the net benefits attached to hydropower projects constructed post-2005. This study extends the sample size by ten projects to cover $68 \mathrm{WBG}$-financed hydropower projects and re-computes the previous 58 hydropower dams' results using a consistent set of data and assumptions. This extended sample will allow for the evaluation of changes that might have taken place in project design and appraisal over time. The larger sample size limits the margin of error in the results and provides greater power to detect differences based on dam size, region, and construction period.

Compared to the earlier study, we were able to obtain more extensive information from the WBG on the hydropower projects. We obtained both ex-ante and ex-post evaluation reports on these projects. Additional information from the WBG enabled a breakdown of the information on four of the projects that contained multiple dams into the data on each of the 12-component hydropower-only dams. This additional information enabled us to make a clear separation of the hydropower dams that were built only for electricity generation from the multipurpose dams. The determination of an alternative generation mix was made by the electricity system planners in the World Bank and those of the corresponding electric utility at the time of the project were being initially appraised. The amounts of electricity that needed to be produced by each of the alternative thermal technologies used in this study were based on the estimates provided at the time of the World Bank appraisal. This information allowed for a more accurate estimation of the thermal generation technologies to be used in this study as the alternative to the hydropower dam. Further analysis was made of the specific reasons identified for the cost and time overruns for each dam. This additional information has given us greater confidence in the overall reliability of the results of the analysis presented in this article.

This is a major improvement compared to the previous study by Awojobi and Jenkins [12], where a rule based only on the expected load factor of the dam was employed to determine if a single cycle or a combined cycle thermal plant would be selected as the single alternative generation technology. Finally, this study explicitly quantifies the benefits of lower carbon emissions due to reduced fossil fuel consumption caused by hydropower projects.

Overall, the focus of this study is four-fold. The first focus is to estimate the net economic benefits of a portfolio of 68 WBG-financed hydropower projects to the societies where they are situated. The second is to re-examine how construction risks (cost and time overruns) affect these projects' net benefits across size, region, and time. The third is to identify the causes of cost and time overruns and determine whether there is a trend in outcomes for projects completed in recent years compared with earlier completions. The fourth is to estimate the beneficial impact of hydropower projects as a renewable energy source on the global environment in terms of carbon emissions' reduction.

\section{Literature Review}

Converting up to $90 \%$ of the available energy into electricity, hydropower dams are among the most efficient way to produce electricity [16]. Despite their efficiency and environmental benefits, hydropower dams are held responsible for considerable negative 
impacts on the ecosystem, on factors such as design, location, and efficiency [17]. Therefore, hydropower projects are broadly evaluated for their overall performance in terms of economic-socio aspects. Maintaining a balance between variables in analysis of the benefits and costs of hydropower dams could be challenging [17], and there is no commonly conventional collection of "input and output" variables for modelling hydropower units [18].

Several methodologies have been employed to evaluate hydropower plants, and none of them can cover the broad environmental and ecological effects of hydropower [19]. The most common methods include life-cycle assessment [20,21], carbon footprint [22,23], carbon emission [24] and ecological-economic assessment [25].

There are few methods that can be used to assess the hydropower projects' economic performance standardly [26]. These methods can be put into three classes [27], including variables for economic performance assessment [28], power production [29], and operational efficiency [26]. The most common criteria when assessing a hydropower project's economic performance include the Net Present Value (NPV) $[30,31]$ and benefit-cost ratio [32]. Of all these methods, the NPV is implemented commonly in hydropower project studies [27].

Cost overruns have been reviewed in the literature [8,9,33,34]. A recent study [10] claimed that $90 \%$ of investments in large dams have cost overruns. These studies propose a considerable bias towards underestimating the capital costs of hydropower dam plants at the design phase compared with the actual costs that are realized upon completion.

A study by [35] derived an estimation of the annual hydro rent in Canada for 1979 based on the production of the public and private electric utilities in hydro provinces, which claimed to account for about $93 \%$ of hydro production by utilities that year. Authors measured "hydroelectric rent" as the yearly flow of savings in economical cost made possible using hydro resources compared with the least cost, an alternative method of generation. The least cost consists of nuclear, coal, and other fossil fuels. The approach is to "compute the difference between the annual economic cost of a hypothetical, least cost, all-thermal system and the current hydrothermal system's annual economic cost to drive an estimate of the hydro rent." The estimation of the economic cost of the two systems involved several significant adjustments to the utility financial account, including moving to a measure of the replacement cost from the historical cost of fixed capital, using a social opportunity cost of fixed capital, and adjusting transmission costs and line losses downward under the hypothetical all-thermal system.

In a study [36] on the Chukha Hydel Project in Bhutan, India financed the project and received a low-priced, reliable hydroelectricity source. Bhutan receives considerable revenue yearly from the exportation of electricity. India can preserve its scarce fossil fuels while achieving a real economic internal rate of return (IRR) no less than $14 \%$. The authors found that the project's cost overrun was approximately $159 \%$ in real terms, which is claimed to be owed to extra engineering provisions to tackle concerns about geological surprises. The estimations of the net economic benefits accruing to Bhutan have been estimated, as of 2008, to be equal to about 2.3 billion (constant 2008) USD, and India has earned to date 2.5 billion (constant 2008 dollars). The authors argued that the estimated share of India's economic benefits would be even higher if the benefits of avoided environmental pollution and carbon emissions are taken into consideration.

Although cost overruns in hydropower dam projects have been widely studied, just a few studies have reflected the benefits of hydropower dams [37,38]. Ultimately, it is important to evaluate the costs and benefits of hydropower development together to truly understand whether the benefits of the technology are justified, given the frequent prevalence of higher than anticipated project costs.

\section{Methodology}

This study proposes an analytical framework that incorporates the uncertainties underlying both the costs and benefits of hydropower dams. The uncertainty underlying the 
cost side is the risk of capital cost and time overruns. The comparison of the costs of generation by the hydropower dams, as compared to a set of thermal generation alternatives, will not provide a fully accurate comparison of the complete systems costs under the hydro and thermal options over a long-time horizon. Such an analysis could be carried out with the construction of alternative least-cost system expansion plans $[39,40]$ with the hydropower and without the hydropower situations. This complete analysis of the alternatives would provide a more accurate comparison of the running, transmission, and reliability costs of the hydro and thermal options. On balance, the comparison of the hydropower and thermal options on generation alone will likely underestimate the benefits of the greater flexibility of the hydropower option.

The uncertainty underlying the benefit side is the volatile fuel price is avoided by undertaking the hydropower investment. To reveal the impact of these risks and uncertainties on the analysis outcome, the authors collect data for completed dams from the World Bank's database: project appraisal documents (PADs), post-evaluation reports such as the implementation and completion reports (ICRs), and other documents. The data on fixed capital and variable costs of open-cycle, combined-cycle, diesel, and coal plants are collected to provide cost estimates for alternative plants avoided by building the hydropower dam.

\subsection{Data}

Data are collected for each of the 68 WBG-financed hydropower projects. Together, these projects account for over 36 gigawatts (GW) of installed power-generation capacity (Table 1, column 2).

Table 1. Summary of projects by type.

\begin{tabular}{ccccccc}
\hline & & & \multicolumn{3}{c}{ (US\$ Million, 2010) } \\
\hline Type of Project & $\begin{array}{c}\text { Number of } \\
\text { Projects }\end{array}$ & $\begin{array}{c}\text { Capacity } \\
\text { (MW) }\end{array}$ & $\begin{array}{c}\text { Real Capital Cost, } \\
\text { Estimated }\end{array}$ & $\begin{array}{c}\text { Real Capital } \\
\text { Cost, Actual }\end{array}$ & $\begin{array}{c}\text { Estimated } \\
\text { Cost/MW }\end{array}$ & $\begin{array}{c}\text { Actual } \\
\text { Cost/MW }\end{array}$ \\
\hline Power-only dams & {$[1]$} & {$[2]$} & {$[3]$} & {$[4]$} & {$[5]$} & {$[6]$} \\
Pumped storage dams & 49 & 24,406 & 33,305 & 42,970 & 1.365 & 1.761 \\
Multipurpose dams & 3 & 3300 & 1839 & 1686 & 0.557 & 0.511 \\
\hline Aggregate & 16 & 8692 & 13,537 & 19,790 & 1.557 & 2.277 \\
\hline
\end{tabular}

Owing to the complexity of quantifying and measuring the benefits of the multipurpose dams and pumped storage dams, the authors divide the 68 WBG hydropower projects into three groups-power-only dams, pumped storage dams, and multipurpose dams - and concentrated on power-only dams. Table 1 shows the composition of data used for this analysis. A total of 49 WBG projects are power-only dams, with a total installed capacity of $24.4 \mathrm{GW}$, three projects are pumped storage dams, with a total installed capacity of $3.3 \mathrm{GW}$, and 16 projects are multipurpose dams, with a total installed capacity of $8.7 \mathrm{GW}$ (Table 1, column 2).

The cost per megawatt (MW) of an installed power station is presented in 2010 constant US dollar (USD) prices. The average cost per MW of capacity of projects when fully implemented is significantly lower for pumped storage dams (US\$0.51 million/MW) than for multipurpose dams (USD 2.28 million/MW) or power-only dams (USD 1.76 million/MW) (Table 1, column 6).

Four of the 49 power-only projects consist of combinations of multiple dams, making the total number of power-only dams 57 . The study of these 57 dams is the focus of the analysis in the remainder of the study. As shown in Table 2. the 57 power-only dams are located in East Asia and the Pacific (16), Latin America and the Caribbean (16), Sub-Saharan Africa (12), Europe and Central Asia (8), and South Asia (5). The average size (in MW) of the projects is much smaller in Sub-Saharan Africa than in Latin America, Asia, Europe, or 
the Caribbean and Pacific islands. The average cost per MW of capacity of projects when fully implemented is significantly lower in East Asia and the Pacific (US\$1.13 million/MW) than in Sub-Saharan Africa (USD 2.81 million/MW), Latin America, and the Caribbean (USD 2.05 million/MW), South Asia (USD 1.93 million/MW), or Europe and Central Asia (USD 1.59 million/MW) (Table 2, column 6).

Table 2. Summary of data by region.

\begin{tabular}{|c|c|c|c|c|c|c|}
\hline \multirow[b]{2}{*}{ Geographical Location } & \multirow[b]{2}{*}{$\begin{array}{l}\text { Number of } \\
\text { Dams }\end{array}$} & \multirow[b]{2}{*}{$\begin{array}{l}\text { Capacity } \\
\text { (MW) }\end{array}$} & \multicolumn{4}{|c|}{ (USD Million, 2010) } \\
\hline & & & $\begin{array}{l}\text { Real Capital Cost, } \\
\text { Estimated }\end{array}$ & $\begin{array}{l}\text { Real Capital } \\
\text { Cost, Actual }\end{array}$ & $\begin{array}{l}\text { Estimated } \\
\text { Cost/MW }\end{array}$ & $\begin{array}{c}\text { Actual } \\
\text { Cost/MW }\end{array}$ \\
\hline & [1] & {$[2]$} & [3] & [4] & [5] & [6] \\
\hline East Asia and Pacific & 16 & 7139 & 6983 & 8099 & 0.978 & 1.134 \\
\hline Europe and Central Asia & 8 & 3106 & 4813 & 4947 & 1.549 & 1.593 \\
\hline Latin America and Caribbean & 16 & 10,283 & 13,428 & 21,032 & 1.306 & 2.045 \\
\hline South Asia & 5 & 2303 & 3998 & 4448 & 1.736 & 1.931 \\
\hline Sub-Saharan Africa & 12 & 1575 & 4066 & 4430 & 2.582 & 2.813 \\
\hline Aggregate & 57 & 24,406 & 33,305 & 42,970 & 1.365 & 1.761 \\
\hline
\end{tabular}

\subsection{Cost Overrun}

Four concepts are used for the analysis of cost overruns [41,42]: estimated nominal cost, estimated real cost, actual nominal cost, and actual real cost. The estimated nominal cost is the sum of base cost (using constant prices) and an amount set aside for physical and price contingencies. The estimated real cost at appraisal is obtained by simply removing the price contingency from the estimated nominal project cost and including the physical contingency. The actual nominal cost is the completion cost of the project expressed in nominal dollar terms. The nominal costs are reported in ICRs of the projects, and the percentage allocation of the actual nominal costs to foreign and local cost components. To calculate the actual real cost, it is necessary to spread the actual nominal cost over the entire project construction period. Drummond's mathematical formulation [43] is used to distribute the capital expenditure over the project construction period. The spreading of the construction costs is carried out using the function:

$$
Y_{i}=\frac{1}{2+p}\left[(s+1)\left(\frac{i}{I}\right)^{s}\left(p+\pi \sin \left(\pi\left(\frac{i}{I}\right)^{s+1}\right)\right)\right]
$$

where $Y_{i}$ is the share of total capital expenditures allocated to period $i$ of the entire construction span that is I years; $S$ represents the skewness of the cost lay-out curve, assumed to be 0.2 for a positively skewed curve over the construction cycle; $p$ is the flatness of the curve, and it varies according to the length of the construction cycle.

The annual nominal costs are first split into foreign and local components and then deflated to the starting year's prices. The domestic costs are converted from nominal USD to nominal domestic currency units using the market exchange rate for each period. The domestic price index deflates these nominal amounts of domestic costs and then converts them back into the USD of the starting year of the project using the market exchange rate for that year. The foreign costs are deflated with the gross domestic product (GDP) deflator index for the USA. These two components are then added to arrive at the project's actual real cost, expressed in dollar terms. The actual real cost (USD) is:

$$
\sum_{i=0}^{T} \frac{C_{i}^{n \$} * F C X}{I_{o, i}^{F}}+\frac{1}{E_{0}^{m}} \sum_{i=0}^{T} \frac{C_{i}^{n \$} *(1-F C X) * E_{i}^{m}}{I_{0, i}^{D}}
$$


where $C^{n \$}$ is the actual nominal cost, FCX is the share of imported components of the total $\operatorname{cost} ; I^{F}$ and $I^{D}$ are the foreign and domestic price indices, respectively. This procedure is used to estimate the actual real costs of constructing the dams (Tables 1 and 2, column 4).

The real cost overrun is calculated as the deviation of the actual real cost from the estimated real cost, taken as a percentage of the estimated real cost. The nominal cost overrun is the percentage deviation of the actual completion cost over the estimated real cost of constructing the dam. This includes both the changes resulting from price increases and the real cost growth in the excess of physical contingencies anticipated during appraisal.

\subsection{Cost of Time Overrun}

Delays during the implementation of a hydropower project may lead to considerable time overrun costs. However, there are both benefits and costs in delaying the construction period beyond its initial schedule. The benefits in present value (PV) terms come from the cost savings of postponed real capital outlays: the actual project cost will be subjected to a longer period of discounting.

$$
\text { Cost savings }=\sum_{i=1}^{T}\left[C_{i}^{r \$} *(1+r)^{-i}\right]-\sum_{j=1}^{Z}\left[C_{j}^{r \$} *(1+r)^{-j}\right]
$$

where $i$ is the construction year within the scheduled period $T ; j$ is the construction year up to the actual completion period $Z ; C^{r \$}$ is the real capital expenditure on the hydro project during construction years.

The costs are the costs of supplying power by alternative means during the delay period, the marginal running cost (MRC) of the alternative power generation, which would include the fuel and variable operating and maintenance (O\&M) costs. The net cost of time overrun is then calculated as the difference between the MRC of the alternative power generation and the cost savings from postponed real investment in hydropower dams (the relevant methodology is presented in Section 3.4).

In Table 3 the cost data are reported for the alternative thermal plants used in this analysis. Carbon factors for different types of fossil fuel, namely, heavy fuel oil (HFO), natural gas (NG), diesel, and coal, are also provided in Table 3.

Table 3. Cost assumptions on alternative thermal plants.

\begin{tabular}{ccccc}
\hline & \multicolumn{4}{c}{ Type of Power Plant } \\
\hline Characteristics & OCGT & CCGT & Diesel & Coal \\
\hline Capital cost (USD/kW) & 900 & 1260 & 650 & 3636 \\
Variable O\&M cost (USD/MWh) & 3.5 & 3.5 & 15.0 & 4.6 \\
Efficiency rating $(\%)$ & $34.1 \%$ & $51.7 \%$ & $34.5 \%$ & $38.8 \%$ \\
Fuel requirement, $\mathrm{HFO}(\mathrm{L} / \mathrm{kWh})$ & 0.252 & 0.167 & 0.250 & - \\
Fuel requirement, NG $(\mathrm{ft} 3 / \mathrm{kWh})$ & 9.747 & 6.433 & 9.649 & - \\
Fuel requirement, diesel $(\mathrm{L} / \mathrm{kWh})$ & 0.259 & 0.171 & 0.257 & - \\
Fuel requirement, coal $(\mathrm{kg} / \mathrm{kWh})$ & - & - & - & 0.405 \\
\hline & $\mathrm{HFO}$ & $\mathrm{NG}$ & Diesel & Coal \\
$\mathrm{CO}_{2}$ factor $\left(\mathrm{CO}_{2} \mathrm{~kg} / \mathrm{kWh}\right)$ & 0.256 & 0.181 & 0.256 & 0.326 \\
\hline
\end{tabular}

Sources: [44-46] and World Bank database of implemented projects (PADs and ICRs). Notes: OCGT, open-cycle gas turbine; CCGT, combined-cycle gas turbine; HFO, heavy fuel oil; NG, natural gas.

\subsection{Measuring the Benefits of Dams}

A hydropower dam's benefit can be measured as the value of the avoided generation cost of the fossil fuel power stations that would need to be built and operated to supply the same amount of electricity as is supplied by the hydropower dam [38]. Assuming that the next best alternative energy can be generated from a standard thermal plant, the benefits of hydropower dams are estimated as: 
- Cost savings on the fixed annual capital cost of the alternative electricity-generation plant;

- $\quad$ MRC of the alternative plant;

- Externality to society and the global environment from the avoided impacts of carbon emissions (Social cost of carbon (SCC)).

The benefit of the hydropower dam is estimated as:

$$
\sum_{t=0}^{Z+40}\left\{\left[K \frac{r(1+r)^{N}}{(1+r)^{N}-1} I C\right]+V O M+\left(f_{t} p_{t}\right) G_{t}+S C C\right\}(1+r)^{-t}
$$

where $K$ is the capital cost and $N$ is the economic life of the alternative plant. IC stands for the installed capacity in MW, and $G$ for the equivalent electricity output expected to be generated by the hydropower dam in period $t$; VOM for variable operating and maintenance costs, $f$ for fuel requirement in liter $/ \mathrm{kWh}$, and $p$ for price of fuel at period $t$. SCC represents the social cost of carbon emission. Fixed operating and maintenance costs are assumed to be equal for both the hydropower dam and the thermal plant [14]. Therefore, these costs are not part of the above formula.

Data on the capital cost of single-cycle, combined-cycle, diesel, and coal-fired power plants are summarized in Table 3. The annual capital cost per $\mathrm{kW}$ is calculated using the annuity formula, where the economic life $(N)$ of the alternative plant is assumed to be 25 years [47]. The fixed annual capital cost is then obtained by multiplying the annual capital cost per $\mathrm{kW}$ with the hydropower dam's installed capacity size.

Four common types of fuel are considered to estimate the hydropower dams' benefits: HFO, NG, diesel, and coal. Details of the type of thermal alternative plant assumed to be displaced by the dam at the project appraisal stage by the project analysts, together with the type of fuel, are collected from the World Bank PADs for each of the 68 projects. The same thermal alternatives are assumed in this analysis. The actual fuel prices for the period 1970-2015 from the US Energy Information Administration (EIA) database [48] are used to calculate hydropower dams' benefits. The fuel prices after 2015 are assumed to be constant at 2015 prices. The fuel prices are adjusted upward by $20 \%$ when calculating the fuel cost for all regions. This margin on the fuel price covers port charges, transportation costs, insurance, and distribution costs [49].

Fuel requirements per kWh for single-cycle, combined-cycle, diesel, and coal-fired power plants are summarized in Table 3 , where the heating values for those plants are assumed to be 10,000 Btu/kWh, $6600 \mathrm{Btu} / \mathrm{kWh}, 9900 \mathrm{Btu} / \mathrm{kWh}$, and $8800 \mathrm{Btu} / \mathrm{kWh}$, respectively [44]. Data for net electricity generation of hydropower dams are available from the World Bank PADs and ICRs for various projects. When there is only one alternative thermal plant assumed at the appraisal stage, the quantity of electricity projected is attributed solely to that plant. However, if the thermal alternatives are different for the peak and off-peak periods, and the amounts of electricity are not explicitly distributed among those periods in the PADs, the authors assume that the peak period lasts for $4 \mathrm{~h}$ a day for 260 days a year [40]. The rest goes to the off-peak period. The variable O\&M costs for the single-cycle, combined-cycle, diesel, and coal-fired power plants are set at USD 3.5 per MWh, USD 3.5 per MWh, USD 15.0 per MWh, and USD 4.6 per MWh, respectively [45].

The social cost of carbon (SCC) emissions is taken from estimates by the Interagency Working Group on the Social Cost of Greenhouse Gases [50]. IWG estimates are used as a guide for estimating the SCC emissions by the World Bank. A real discount rate of $10 \%$ is used to bring both benefits and costs to the same period.

Once the benefits of the hydropower projects are estimated, the dams' net benefit is derived by subtracting the dam projects' actual cost from their estimated benefits and then expressed as the stream of net benefits over time in real PV terms, using 2016 as the base year. The value of electricity estimated in this study includes all generation costs but does not include any differentiated transmission and distribution costs if these were not included in the project reports. 


\section{Results and Discussion}

\subsection{Findings on Cost Overruns}

The distribution of real cost overruns by the dam for our sample of 57 power-only dams has a mean of $24 \%$ and a standard deviation of $42 \%$. Real cost overruns range from $-41.8 \%$ to $176.7 \%$ of the estimated real costs. Over $70 \%$ of the projects experienced overruns, with half of the overruns within the $0-25 \%$ range. The distribution of real cost overruns is positively skewed; the coefficient of skewness is 1.53 .

Both the impacts of inflation and the real cost overruns are reported in Table 4 . The averages are the weighted averages of the various dams, where the weights are the proportions of the MWs of capacity represented by each dam in the total sample. As shown in column 2, the cumulative movements in prices have, on average, increased the nominal cost of these dams by $52.6 \%$ of the estimated real base cost. The estimated real base cost includes the non-price contingencies that are usually included at the appraisal time but excludes the price contingencies. The total nominal escalation of costs ranges from $87.4 \%$ of base cost estimates in Latin America and the Caribbean to 13\% in Europe and Central Asia. In East Asia and Pacific, Sub-Saharan Africa, and South Asia, the nominal cost escalation rates are $35.5 \%, 31.0 \%$, and $18.4 \%$, respectively. The dams implemented in Latin America and the Caribbean have suffered more from inflation than those in other regions.

Table 4. Estimated average cost overruns across regions.

\begin{tabular}{|c|c|c|c|c|c|}
\hline Region & $\begin{array}{l}\text { Number } \\
\text { of Dams }\end{array}$ & $\begin{array}{l}\text { Nominal Cost } \\
\text { Overrun as } \\
\text { Percentage of } \\
\text { Estimated Real } \\
\text { Cost }(\%)\end{array}$ & $\begin{array}{c}\text { Estimated Price } \\
\text { Contingency as } \\
\text { Percentage of } \\
\text { Estimated Real } \\
\text { Cost }(\%)\end{array}$ & $\begin{array}{c}\text { Actual Price } \\
\text { Escalation as } \\
\text { Percentage of } \\
\text { Estimated Real } \\
\text { Cost }(\%)\end{array}$ & $\begin{array}{c}\text { Real Cost } \\
\text { Overrun as } \\
\text { Percentage of } \\
\text { Estimated Real } \\
\text { Cost }(\%)\end{array}$ \\
\hline & [1] & [2] & [3] & [4] & [5] \\
\hline East Asia and Pacific & 16 & 35.57 & 22.22 & 15.36 & 20.22 \\
\hline Europe and Central Asia & 8 & 12.99 & 12.07 & 10.29 & 2.70 \\
\hline $\begin{array}{c}\text { Latin America and } \\
\text { Caribbean }\end{array}$ & 16 & 87.37 & 18.02 & 32.17 & 55.20 \\
\hline South Asia & 5 & 18.44 & 16.59 & 5.26 & 13.18 \\
\hline Sub-Saharan Africa & 12 & 30.96 & 17.60 & 21.14 & 9.82 \\
\hline Weighted average & 57 & 52.61 & 18.33 & 21.22 & 31.39 \\
\hline Weighted average* & 51 & 44.93 & 17.24 & 21.30 & 23.64 \\
\hline East Asia and Pacific * & 15 & 35.50 & 22.22 & 15.36 & 20.15 \\
\hline $\begin{array}{l}\text { Latin America and } \\
\text { Caribbean * }\end{array}$ & 12 & 75.07 & 16.12 & 34.48 & 40.60 \\
\hline South Asia * & 4 & 7.25 & 12.50 & 2.17 & 5.08 \\
\hline
\end{tabular}

Notes: * Excluding three outliers in Latin America and the Caribbean, one outlier in East Asia and the Pacific, and one outlier in South Asia (based on the analysis of the distribution of real cost overrun).

The weighted average real cost overrun is calculated as $31.4 \%$ of the estimated real cost for the sample of 57 power-only dams. This number falls to $23.6 \%$ of the estimated real cost if we exclude five outliers in our sample of 57 dams. The analysis of the real cost overruns' distribution shows that there are five outliers in the dataset, and the highest number of outliers is in Latin America and the Caribbean: three out of five outliers. The remaining two outliers are in East Asia and the Pacific and South Asia.

The lowest real cost overruns are found for the eight dams built in Europe and Central Asia, averaging only $2.7 \%$ over those projected by region. Europe and Central Asia's experience contrasts with that of Latin America and the Caribbean, where real costs are, on average, $55.2 \%$ higher than initial estimates, with a cost overrun more than twentyfold those estimated for Europe and Central Asia. Even after removing the outliers, the estimated real cost overrun in Latin America and the Caribbean stands at $40.7 \%$ of the estimated real cost; this is still much higher than the whole sample's weighted average. 
Every country in Latin America and the Caribbean has witnessed very high real cost overruns. Pehuenche dam in Chile and Aguamilpa dam in Mexico have witnessed real cost overruns of $-42.8 \%$ and $-6.2 \%$, respectively, of the estimated real costs. However, these are the only cases where the real cost overruns are low in Latin America and the Caribbean. In the same countries, other dams have had high real cost overruns, such as La Huguera dam in Chile and Zimapan dam in Mexico, with 80.9\% and 77.9\%, respectively, of the estimated real costs.

The average real cost overrun is also low in Sub-Saharan Africa, at $9.8 \%$ of the estimated real costs. This is followed by South Asia, where the average real cost overrun is $13.2 \%$ of the estimated real costs. This value falls further to $5.1 \%$ if the outlier is removed from the calculation.

The average real cost overrun for dams in East Asia and the Pacific is $20.2 \%$ of the estimated cost. After removing the outlier, the weighted average real cost overrun is still almost the same as if the outlier was not removed. The outlier dam's capacity is very small, making little difference when it is removed.

To look more deeply at the reasons for the cost overruns, each of the ICRs is reviewed to find the factors that have led to the cost overrun. The reasons for this are summarized in Figure 1 .

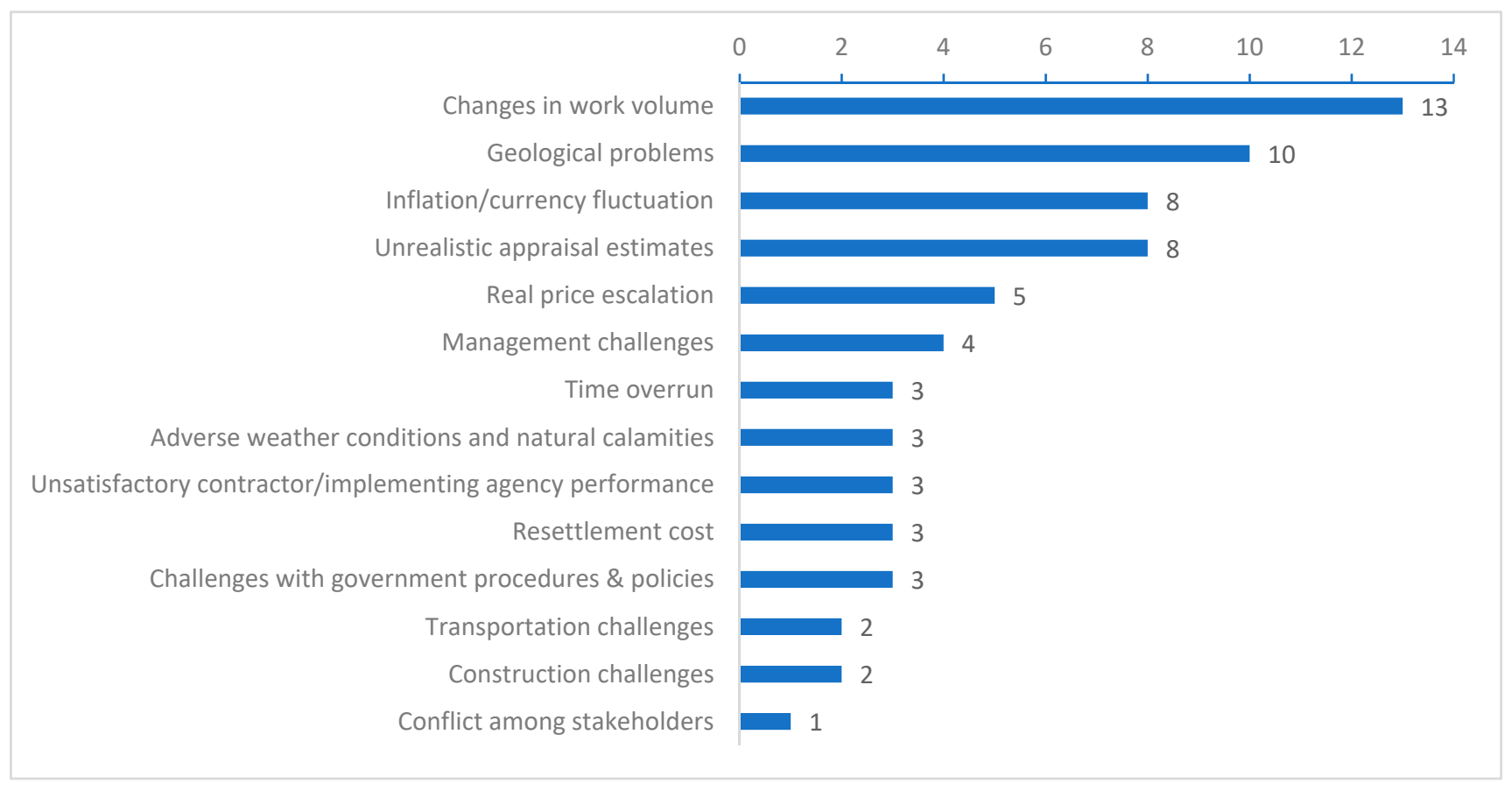

Figure 1. Causes of cost overruns (summary).

Five reasons account for $64.7 \%$ of the total reasons for the cost overruns: change in work volume, geological problems, inflation/currency fluctuations, unrealistic appraisal estimates, and real price escalation. Resettlement costs are identified as a significant cause of cost overruns in only three cases. The World Bank appears to have dealt effectively with these issues before the start of the projects. However, other implementation issues, such as unsatisfactory contractor/implementing agency performance, management challenges, transportation challenges, challenges with government procedures and policies, and construction challenges, account for a total of 14 of the reasons given for the cost overruns. The "force majeure"-type challenges of geology and adverse weather conditions account for 13 reasons, a similar number to the incidence of implementation problems and changes in work volumes.

Clearly, the project managers and consultants who planned these projects underestimated both the average magnitude and the range of physical contingencies required by 
these dam projects. The uncertainty in estimating costs and implementation challenges has led to a very significant downward bias in the estimated costs compared with actual experience.

Table 5 shows the data analysis results for the incidence of cost overrun by the size of hydropower-generation capacity installed (MW), which is further filtered by the type of dam (with or without storage). There is no simple linear relationship between the degree of cost overrun and a dam's capacity, or between cost overrun and the type of dam. However, dams of larger size, with an installed capacity above $700 \mathrm{MW}$, perform much poorer in cost planning.

Table 5. Incidence of cost overrun by size of installed capacity.

\begin{tabular}{|c|c|c|c|c|c|}
\hline $\begin{array}{l}\text { Size: Installed } \\
\text { Capacity (MW) }\end{array}$ & $\begin{array}{l}\text { Number } \\
\text { of Dams }\end{array}$ & $\begin{array}{l}\text { Actual Real Cost } \\
\text { Growth as } \\
\text { Percentage of } \\
\text { Estimated Real } \\
\text { Cost }(\%)\end{array}$ & $\begin{array}{l}\text { Estimated Physical } \\
\text { Contingencies as } \\
\text { Percentage of } \\
\text { Estimated Real } \\
\text { Cost }(\%)\end{array}$ & $\begin{array}{c}\text { Real Cost } \\
\text { Overrun as } \\
\text { Percentage of } \\
\text { Estimated Real } \\
\text { Cost }(\%)\end{array}$ & $\begin{array}{l}\text { Nominal Cost } \\
\text { Overrun as } \\
\text { Percentage of } \\
\text { Estimated Real } \\
\text { Cost }(\%)\end{array}$ \\
\hline & [1] & [2] & [3] & [4] & [5] \\
\hline 0-99 & 19 & 18.71 & 8.77 & 9.93 & 24.54 \\
\hline WS & 9 & 23.64 & 9.18 & 14.46 & 31.03 \\
\hline WOS & 10 & 15.17 & 8.48 & 6.69 & 19.89 \\
\hline 100-299 & 18 & 40.03 & 8.89 & 31.13 & 47.60 \\
\hline WS & 10 & 31.93 & 10.01 & 21.92 & 38.47 \\
\hline WOS & 8 & 50.16 & 7.50 & 42.66 & 59.04 \\
\hline $300-699$ & 10 & 22.20 & 9.30 & 12.90 & 28.90 \\
\hline WS & 9 & 22.06 & 9.42 & 12.64 & 28.82 \\
\hline WOS & 1 & 23.51 & 8.27 & 15.24 & 29.68 \\
\hline 700-1499 & 6 & 54.22 & 11.32 & 42.90 & 50.29 \\
\hline WS & 5 & 67.75 & 11.69 & 56.06 & 66.07 \\
\hline WOS & 1 & 7.59 & 10.07 & -2.49 & -4.12 \\
\hline 1500 and above & 4 & 44.23 & 10.42 & 33.81 & 68.75 \\
\hline WS & 4 & 44.23 & 10.42 & 33.81 & 68.75 \\
\hline WOS & 0 & 0.00 & 0.00 & 0.00 & 0.00 \\
\hline Weighted average & 57 & 41.59 & 10.20 & 31.39 & 52.61 \\
\hline
\end{tabular}

Notes: WS, with storage; WOS, without storage.

Table 5, column 4, shows that, on average, dams with a capacity of 700-1499 MW have, by the time of completion, cost overruns of $42.9 \%$ of real cost estimates at appraisal. Projects above $1500 \mathrm{MW}$ capacity have average real cost overruns of $33.8 \%$. Very small dams (0-99 MW) seem to have much better estimates at appraisal, with relatively lower real cost overruns of $9.9 \%$ on average of the real cost estimates during planning. This is followed by medium (300-699 MW) and small (100-299 MW) projects, with average real cost overruns of $12.9 \%$ and $31.1 \%$, respectively, of the real cost estimates during planning.

Physical contingency estimates do not differ much for the various size categories: the physical contingency estimate is about $9-11 \%$ of real cost estimates (Table 5 , column 3 ). This shows evidence of a common methodology used by the World Bank in estimating physical contingencies.

At the appraisal stage, an average $18.3 \%$ change in price level is projected for the 57 dams in this study (Table 6, column 4). The actual results show a $21.2 \%$ change in nominal costs due to price escalation (Table 6, column 5). Considering the error between the estimated price contingency and the actual price escalation, expressed as a percentage of estimated real cost, the average error due to the inflation forecast is only $2.9 \%$ points. This reveals that, on average, the inflation forecasts for cost projections in the World Bank projects have not been systematically biased over the entire period for this portfolio of dams. However, errors in the forecasting of prices from project to project may be a significant source of risk when planning the financing arrangements of such schemes. 
Table 6. Comparison of cost overruns for different periods.

\begin{tabular}{|c|c|c|c|c|c|c|}
\hline $\begin{array}{l}\text { Projects } \\
\text { Completed }\end{array}$ & $\begin{array}{c}\text { Number of } \\
\text { Dams }\end{array}$ & $\begin{array}{c}\text { Estimated } \\
\text { Physical } \\
\text { Contingencies } \\
\text { as Percentage } \\
\text { of Estimated } \\
\text { Real Cost (\%) }\end{array}$ & $\begin{array}{c}\text { Real Cost } \\
\text { Overrun as } \\
\text { Percentage of } \\
\text { Estimated Real } \\
\text { Cost }(\%)\end{array}$ & $\begin{array}{c}\text { Estimated } \\
\text { Price } \\
\text { Contingency } \\
\text { as Percentage } \\
\text { of Estimated } \\
\text { Real Cost (\%) }\end{array}$ & $\begin{array}{l}\text { Actual Price } \\
\text { Escalation as } \\
\text { Percentage of } \\
\text { Estimated Real } \\
\text { Cost }(\%)\end{array}$ & $\begin{array}{l}\text { Nominal Cost } \\
\text { Overrun as } \\
\text { Percentage of } \\
\text { Estimated Real } \\
\text { Cost }(\%)\end{array}$ \\
\hline & [1] & [2] & [3] & [4] & [5] & [6] \\
\hline 1975-1987 & 21 & 10.46 & 47.37 & 19.04 & 36.07 & 83.44 \\
\hline 1988-1997 & 20 & 10.58 & 30.54 & 21.75 & 9.18 & 39.71 \\
\hline 1998-2015 & 16 & 9.40 & 10.53 & 13.28 & 15.25 & 25.78 \\
\hline Weighted average & 57 & 10.20 & 31.39 & 18.33 & 21.22 & 52.61 \\
\hline
\end{tabular}

There is evidence here of substantial learning since 1998 in relation to price level projections by World Bank project appraisers. The results for the 16 dams completed between 1998 and 2015 are, on average, the most accurate predictions. The weighted average price contingency proposed by the World Bank analysts is $13.3 \%$, while the actual weighted average price increase experienced is $15.3 \%$. The average error due to the inflation forecast is only two percentage points.

This is not the case for the dams completed in earlier periods. The price levels are either underestimated or overestimated well below or above the actual price levels. The weighted average price contingency proposed by the World Bank analysts for 21 dams completed between 1975 and 1987 is 19\%, while the actual weighted average price increase experienced is $36.1 \%$. More than 17 percentage points underestimate the average error due to the inflation forecast. The converse is the case for the period 1988-1997. The weighted average price contingency proposed by the World Bank analysts for 20 dams completed between 1988 and 1997 is $21.8 \%$, while the actual weighted average price increase experienced is only $9.2 \%$. A total of 12.6 percentage points overestimate the average error due to the inflation forecast.

In Table 6, a comparison is made between, on one side, the cost overrun estimations for the 21 hydropower dams included in the dataset used by Bacon et al. [51] and completed before 1987 and, on the other, the measured cost overrun of dams completed between 1988 and 2015. There is evidence here of substantial learning since 1998. The level of real cost overrun in 1988-1997 is more than $16.8 \%$ lower, at $30.5 \%$ of the estimated real cost than that in the period prior to 1987, when it is $47.4 \%$. Furthermore, in the period following 1998, the real cost overrun continues to fall. It reduces dramatically to $10.5 \%$, an almost five-fold reduction in real cost overrun compared to the period before 1987 (Table 6, column 3).

The next step is to understand and identify the possible reasons, if any, for the substantial reduction in the real cost overrun over time. Therefore, the authors investigate whether there is any relationship between the size of the dam and the year of completion, the type of dam (with or without storage), and the year of completion. Table 7 is a cross tabulation showing the types and sizes of dams, and how many of them were built in each time period.

As shown in Table 7, the type of dam that WBG has financed has shifted over time from those with storage to more of those without storage, and the average size of dams has reduced. This is one possible explanation for why the real cost overrun has reduced dramatically over time. 
Table 7. Type and size of the dams for different periods.

\begin{tabular}{|c|c|c|c|}
\hline \multirow{2}{*}{\multicolumn{2}{|c|}{ Dams Completed (between) }} & \multicolumn{2}{|c|}{ Number of Dams by Type, and Average Size (MW) } \\
\hline & & WS & WOS \\
\hline \multicolumn{2}{|c|}{ 1975-1987 } & 14 & 7 \\
\hline \multirow{2}{*}{$\begin{array}{c}\text { Average capacity } \\
\text { Average capacity } \\
\text { excluding outliers * }\end{array}$} & $447 \mathrm{MW}$ & $618 \mathrm{MW}$ & $105 \mathrm{MW}$ \\
\hline & $171 \mathrm{MW}$ & $217 \mathrm{MW}$ & $105 \mathrm{MW}$ \\
\hline \multicolumn{2}{|c|}{$1988-1997$} & 17 & 3 \\
\hline \multirow{2}{*}{$\begin{array}{c}\text { Average capacity } \\
\text { Average capacity } \\
\text { excluding outliers * }\end{array}$} & $409 \mathrm{MW}$ & $464 \mathrm{MW}$ & $93 \mathrm{MW}$ \\
\hline & $336 \mathrm{MW}$ & $381 \mathrm{MW}$ & $93 \mathrm{MW}$ \\
\hline \multicolumn{2}{|c|}{$1998-2015$} & 6 & 10 \\
\hline \multirow{2}{*}{$\begin{array}{c}\text { Average capacity } \\
\text { Average capacity } \\
\text { excluding outliers * }\end{array}$} & $428 \mathrm{MW}$ & $666 \mathrm{MW}$ & $285 \mathrm{MW}$ \\
\hline & $150 \mathrm{MW}$ & $140 \mathrm{MW}$ & $156 \mathrm{MW}$ \\
\hline
\end{tabular}

Notes: * Average capacity for this time period excluding outliers (based on the distribution analysis of dam capacities for each time period). WS, with storage; WOS, without storage.

\subsection{Findings on Time Overruns}

The majority of dams in this study experienced time overruns, with an average time overrun of 13.8 months or $20.2 \%$ of the project's scheduled completion time. This is the weight-adjusted average of installed capacity for each project to the total installed capacity for all the projects in this sample. More than $77 \%$ of the sample projects experienced a time overrun of more than $10 \%$ of the initial time estimated for completion. The time overrun's overall net cost is $11.1 \%$ of the estimated real construction cost (Table 8 , column 7). This cost could have been avoided if there had been no delays in construction. In South Asia, all five projects experienced significant time overrun. The average time overrun is $33.1 \%$ of the estimated construction schedule at the appraisal stage, and the cost of time overrun to society averages $28.7 \%$ of the project's estimated real cost.

Table 8. Incidence and cost of time overruns across various regions.

\begin{tabular}{|c|c|c|c|c|c|c|c|}
\hline Region & $\begin{array}{l}\text { Number } \\
\text { of Dams }\end{array}$ & $\begin{array}{c}\text { Number of } \\
\text { Dams with } \\
\text { Time Overrun }\end{array}$ & $\begin{array}{l}\text { Average } \\
\text { Capacity } \\
\text { (MW) }\end{array}$ & $\begin{array}{l}\text { Scheduled } \\
\text { (Months) }\end{array}$ & $\begin{array}{l}\text { Slippage } \\
\text { (Months) }\end{array}$ & $\begin{array}{c}\text { Average } \\
\text { Time } \\
\text { Overrun (\%) }\end{array}$ & $\begin{array}{c}\text { Cost of Time Overrun as } \\
\text { Percentage of Estimated } \\
\text { Real Costs }(\%)\end{array}$ \\
\hline & [1] & {$[2]$} & [3] & [4] & [5] & [6] & [7] \\
\hline East Asia and Pacific & 16 & 13 & 446 & 90.7 & 3.2 & 5.27 & 3.62 \\
\hline Europe and Central Asia & 8 & 8 & 388 & 81.0 & 17.1 & 22.04 & 18.15 \\
\hline $\begin{array}{c}\text { Latin America and } \\
\text { Caribbean }\end{array}$ & 16 & 14 & 643 & 75.8 & 18.5 & 26.94 & 10.42 \\
\hline South Asia & 5 & 5 & 461 & 73.9 & 23.6 & 33.14 & 28.68 \\
\hline Sub-Saharan Africa & 12 & 9 & 131 & 53.0 & 11.1 & 21.25 & 9.26 \\
\hline Weighted average & 57 & 49 & 428 & 79.2 & 13.8 & 20.20 & 11.06 \\
\hline
\end{tabular}

In Europe and Central Asia, time overruns occurred in all eight projects implemented in this analysis. The average time slippage is 17.1 months, or $22 \%$ of the estimated construction schedule, at the cost of $18.2 \%$ of the projects' estimated real cost. In Sub-Saharan Africa, time overruns occurred in 9 of the 12 projects in this analysis. The average time slippage is 11.1 months, or $21.3 \%$ of the estimated construction schedule, at the cost of $9.3 \%$ of the projects' estimated real cost. In Latin America and the Caribbean, time overruns occurred in 14 of the 16 projects in this analysis. The average time slippage is 18.5 months, or $26.9 \%$ of the estimated construction schedule, at the cost of $10.4 \%$ of the projects' estimated real cost.

Projects in East Asia and the Pacific show better implementation performances than those in other regions. The construction schedule estimates at appraisal are more realistic. With an average construction schedule of 90.7 months, the average delay in completion 
is only 3.2 months and the associated cost to society of this overrun averages $3.6 \%$ of the estimated real cost.

The underlying causes of the time overruns, as reported in Figure 2, are quite varied. The five reasons most frequently given are geological problems (15), conflict among stakeholders (12), adverse weather and national calamities (11), financing (11), and delay in equipment delivery (9). The next five most important identified causes are challenges from government procedures and policies (7), changes in work volume (7), management challenges (7), delays in the bidding/award process (6), and construction challenges (6). Interestingly, among the top ten factors causing time overruns, only two, geological problems and changes in work volumes, rank in the top five causes of real cost overruns.

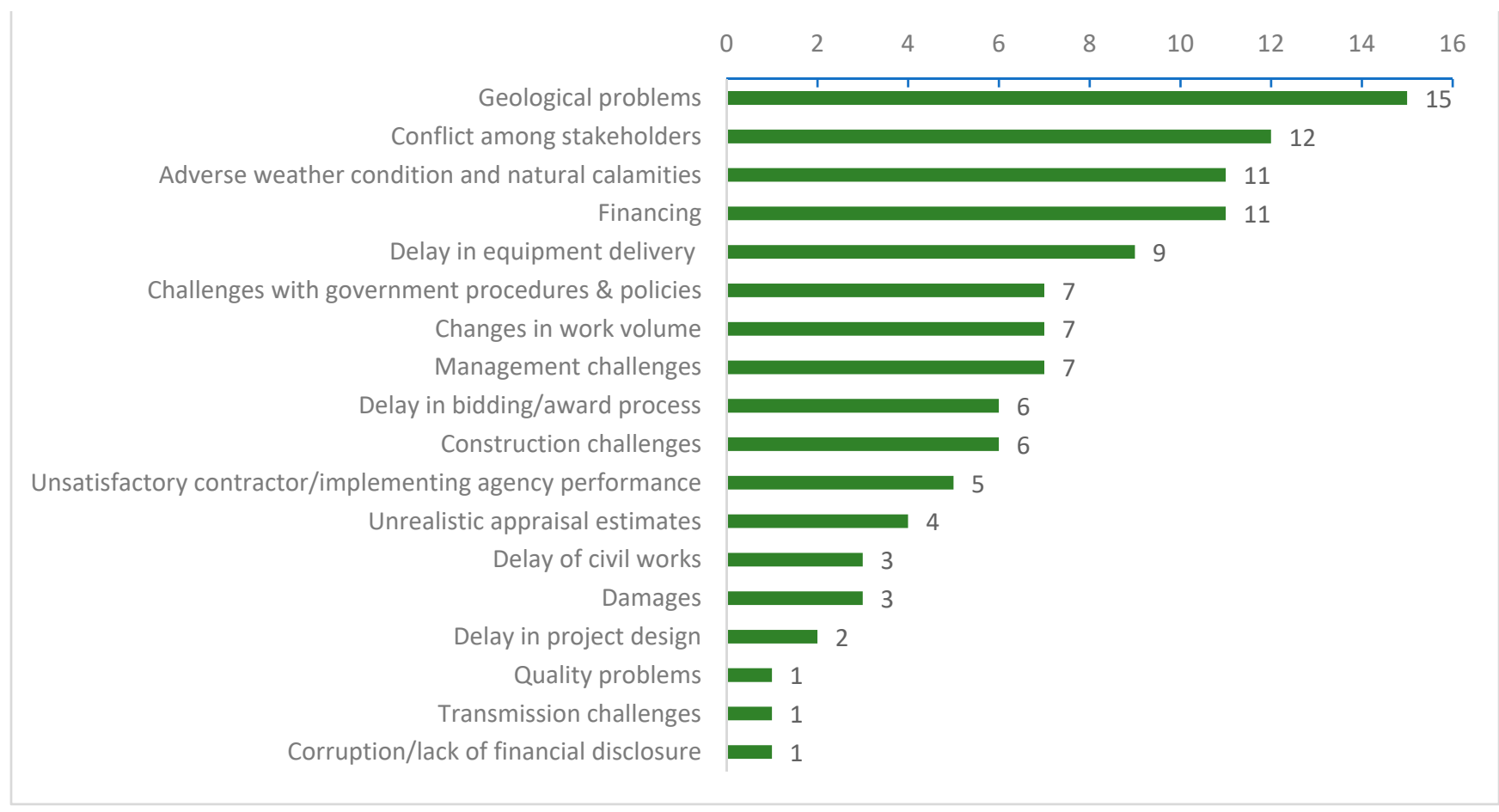

Figure 2. Causes of time overruns (summary).

In addition to the findings on the severity of time overrun across regions, we investigate whether the bias in the estimated time for constructing these dams varies by size and type (with or without storage) of the dam. Table 9 summarizes the variations between the scheduled length of construction and the actual completion period of dams, distributed according to size and type of dam.

Table 9, column 4 shows the time overrun across the various sizes of hydropower projects. While the average time overrun for all 57 dams is $20.2 \%$ of the scheduled time, there is a large difference between the time overrun of the four large dams $(>1500 \mathrm{MW}$ capacity), at an average of only $8.5 \%$, and that of the remaining 53 dams, at an average of $29.4 \%$ of the initially scheduled time for completion.

In terms of the time overruns' costs, the highest costs are incurred by the smallest dams (0-99 MW) at an average of $34.2 \%$ of the estimated real costs (Table 9, column 5). This is followed by large (700-1499 MW), very large (above $1500 \mathrm{MW}$ ), and medium (300$699 \mathrm{MW}$ ) dams, with averages of $14 \%, 9.5 \%$, and $8.3 \%$, respectively, of cost of time overrun as a percentage of estimated real costs. Smaller dams (100-299 MW) have relatively smaller amounts of cost of time overrun, at $6.4 \%$ of the estimated costs. The very large dams are more efficient electricity generators than the smaller dams. The cost of time overruns associated with a smaller slippage in schedule is proportionally much higher than in the smaller dams. The time slippage was much larger. Still, the cost of the time overruns was proportionally smaller. 
Table 9. Distribution of the cost of time overrun by size.

\begin{tabular}{cccccc}
\hline $\begin{array}{c}\text { Size: Installed } \\
\text { Capacity } \\
\text { (MW) }\end{array}$ & $\begin{array}{c}\text { Number } \\
\text { of Dams }\end{array}$ & $\begin{array}{c}\text { Scheduled } \\
\text { (Months) }\end{array}$ & $\begin{array}{c}\text { Slippage } \\
\text { (Months) }\end{array}$ & $\begin{array}{c}\text { Average Time } \\
\text { Overrun (\%) }\end{array}$ & $\begin{array}{c}\text { Cost of Time Overrun as } \\
\text { Percentage of Estimated } \\
\text { Real Costs (\%) }\end{array}$ \\
\hline 0-99 & {$[1]$} & {$[2]$} & {$[3]$} & {$[4]$} & {$[5]$} \\
WS & 19 & 58.3 & 20.2 & 37.90 & 34.23 \\
WOS & 9 & 64.0 & 17.9 & 29.90 & 42.49 \\
100-299 & 10 & 54.2 & 21.9 & 43.63 & 28.32 \\
WS & 10 & 57.0 & 14.2 & 28.48 & 3.42 \\
WOS & 8 & 62.4 & 10.6 & 18.07 & 9.91 \\
300-699 & 10 & 50.2 & 18.7 & 41.51 & 8.25 \\
WS & 9 & 64.2 & 12.9 & 20.39 & 8.40 \\
WOS & 1 & 59.7 & 12.0 & 18.69 & 6.94 \\
$700-1499$ & 6 & 76.2 & 21.0 & 35.59 & 6.99 \\
WS & 5 & 73.9 & 22.6 & 30.82 & 39.88 \\
WOS & 1 & 84.0 & 24.2 & 31.47 & 9.53 \\
1500 and above & 4 & 97.1 & 7.6 & 28.57 & 9.53 \\
WS & 4 & 97.1 & 7.6 & 8.45 & 0.00 \\
WOS & 0 & 0.0 & 0.0 & 0.45 & 11.06 \\
\hline Weighted & 57 & 79.2 & 13.8 & 20.20 & \\
average & & & & & \\
\hline
\end{tabular}

Notes: WS, with storage; WOS, without storage.

Bacon et al. [9] found that the average slippage in the actual construction length of hydropower projects was $28 \%$ of the time scheduled. In Table 10, a comparison is made between the 21 dams completed prior to 1987 and those completed after 1987. The slippage time decreases to 9.9 months for the projects completed after 1998 compared with the ones completed before 1998, but at a higher cost. This occurs because, compared with the thermal alternatives, the hydropower dams built since 1998 are lower-cost generators of electricity than dams built before 1998. The average time overrun as a percentage of the initially scheduled time for the projects completed after 1998 falls to $17.8 \%$ from the average value of $30.4 \%$ for $1988-1997$. The cost of time overrun as a percentage of the estimated real costs increases to $16.4 \%$ in the period after 1998, 72\% higher than that of 1975-1987, and almost twice that of the period 1988-1997. It is clear that, as the cost of thermal-generated electricity rises with increases in fuel prices, the loss to the country rises from the delay in the supply of lower-cost hydro-generated electricity.

Table 10. Comparison of cost of time overruns for different periods.

\begin{tabular}{|c|c|c|c|c|c|c|}
\hline $\begin{array}{l}\text { Projects } \\
\text { Completed } \\
\text { (between) }\end{array}$ & $\begin{array}{l}\text { Number } \\
\text { of Dams }\end{array}$ & $\begin{array}{c}\text { Average } \\
\text { Capacity (MW) }\end{array}$ & $\begin{array}{l}\text { Scheduled } \\
\text { (Months) }\end{array}$ & $\begin{array}{l}\text { Slippage } \\
\text { (Months) }\end{array}$ & $\begin{array}{l}\text { Average Time } \\
\text { Overrun (\%) }\end{array}$ & $\begin{array}{c}\text { Cost of Time Overrun as } \\
\text { Percentage of Estimated } \\
\text { Real Costs }(\%)\end{array}$ \\
\hline & [1] & [2] & [3] & [4] & [5] & [6] \\
\hline 1975-1987 & 21 & 447 & 78.1 & 10.2 & 12.99 & 9.57 \\
\hline 1988-1997 & 20 & 409 & 73.5 & 21.3 & 30.44 & 8.29 \\
\hline 1998-2015 & 16 & 428 & 87.4 & 9.9 & 17.84 & 16.42 \\
\hline Weighted average & 57 & 428 & 79.2 & 13.8 & 20.20 & 11.06 \\
\hline
\end{tabular}

The estimated cost of time overruns in these results is smaller than the magnitude of the real cost overruns. While the extension to the implementation schedules for the completion of the dams may be significant in terms of calendar months, the real costs imposed by these delays are $11.1 \%$ of the initial real cost estimate for the projects. These estimates include the impact of the delay on both the PV of construction costs and the $\mathrm{PV}$ of the electricity system's increased running costs as it tries to make up for the loss in electricity generated by the dams as a result of the delay. 
However, the loss from time costs as measured here is a loss to the economy due to the loss of a low-cost service. This is usually neglected when considering the cost of time delays. This cost is over and above the additional costs incurred to complete a facility's construction that a time delay might impose.

\subsection{Findings on Net Benefits of Hydropower Dams}

The discrepancy between the appraisal and the actual rates of return of dams in this study is analyzed based on the 'avoided cost' methodology for electricity generation. Here, the hydropower dams' economic benefits are measured as the cost savings that would be incurred by generating an equivalent amount of electricity with a similar load factor with a configuration of alternative thermal technologies. The rates of return of this portfolio of dams are estimated twice. First, we estimate the ex-ante rates of return based on the estimated construction costs of the dams at the time of appraisal. Second, the rates of return are calculated based on the actual construction costs of the dams. The results are presented in Table 11, by region.

Table 11. Estimated vs. actual EIRR by region.

\begin{tabular}{|c|c|c|c|c|c|c|c|c|c|}
\hline Region & $\begin{array}{l}\text { Number } \\
\text { of Dams }\end{array}$ & $\begin{array}{c}\text { Total } \\
\text { Capacity } \\
\text { Installed } \\
(\mathrm{MW})\end{array}$ & $\begin{array}{c}\text { PV of } \\
\text { Estimated Costs } \\
@ 10 \% \text { (USD } \\
\text { Million, 2016) }\end{array}$ & $\begin{array}{l}\text { PV of Actual } \\
\text { Costs @ } 10 \% \\
\text { (USD Million, } \\
\text { 2016) }\end{array}$ & $\begin{array}{c}\text { PV of } \\
\text { Benefits @ } \\
\text { 10\% (USD } \\
\text { Million, } \\
\text { 2016) }\end{array}$ & $\begin{array}{l}\text { Net PV of } \\
\text { Hydro @ } \\
\text { 10\% (USD } \\
\text { Million, } \\
\text { 2016) }\end{array}$ & $\begin{array}{c}\text { Ex-ante } \\
\text { EIRR } \\
(\%)\end{array}$ & $\begin{array}{c}\text { Ex-post } \\
\text { EIRR } \\
(\%)\end{array}$ & $\begin{array}{c}\text { Number of } \\
\text { Dams with } \\
\text { Actual } \\
\text { Negative NPV }\end{array}$ \\
\hline & [1] & [2] & [3] & [4] & [5] & [6] & [7] & [8] & [9] \\
\hline $\begin{array}{c}\text { East Asia and } \\
\text { Pacific }\end{array}$ & 16 & 7139 & 116,132 & 137,123 & 237,341 & 100,218 & 18.5 & 17.0 & 2 \\
\hline $\begin{array}{l}\text { Europe and } \\
\text { Central Asia }\end{array}$ & 8 & 3106 & 108,461 & 113,472 & 170,921 & 57,449 & 13.7 & 13.5 & 1 \\
\hline $\begin{array}{l}\text { Latin America } \\
\text { and Caribbean }\end{array}$ & 16 & 10,283 & 348,008 & 553,300 & 785,442 & 232,142 & 17.0 & 13.7 & 8 \\
\hline South Asia & 5 & 2303 & 29,381 & 32,168 & 82,145 & 49,977 & 21.7 & 21.0 & 2 \\
\hline $\begin{array}{c}\text { Sub-Saharan } \\
\text { Africa }\end{array}$ & 12 & 1575 & 104,344 & 116,055 & 205,669 & 89,614 & 16.1 & 15.1 & 2 \\
\hline Total & 57 & 24,405 & 706,327 & 952,118 & $1,481,519$ & 529,401 & 17.4 & 15.4 & 15 \\
\hline
\end{tabular}

In this study, the internal rates of return are the discount rates at which the estimated benefits associated with the avoided costs of the dams over the projects' operating life are equal to the actual costs of the dams. This analysis is carried out both excluding the SCC at USD 39 and including this positive global externality of hydropower dams.

The differences between the estimated ex-ante and ex-post rates of return are directly associated with the magnitude of the cost overruns included in the estimated ex-post rates of return. Intuitively, the systematic pattern of errors in cost projections identified in the study suggests that the ex-post rates of returns are more likely to be somewhat below their estimated ex-ante values.

The quantities and load factor of the electricity generated by each hydropower dam are those projected at the appraisal stage. Any loss of output due to delays in the dam completion is accounted for in the analysis. When the dam is delayed, the benefit projected profile is shifted to the period when the dam actually begins operations. Hence, the benefits of the dam will have a lower PV. The benefits of the individual dams-that is, the cost savings from not employing the replacement plant-are estimated using actual data for $\mathrm{HFO}, \mathrm{NG}$, diesel, and coal prices corresponding to each of the years the hydropower dams have operated to date. For periods from 2015 to the end of the hydropower dams' life cycle (40 years), the HFO, NG, diesel, and coal prices are assumed to be fixed in real terms at USD 356.5 per tonne, USD 5.6 per thousand cubic feet, USD 737.1 per tonne, and USD 93.2 per tonne, respectively.

For the 57 dams in this study, the average ex-ante rate of return, excluding the benefits of carbon emissions avoided by these hydropower dams, estimated at the time of appraisal for the whole portfolio, is $17.4 \%$. In contrast, the ex-post average rate of return is $15.4 \%$. Both the ex-ante and the estimated ex-post rates of return exclude the external benefits of 
reduced greenhouse gas (GHG) emissions due to the substitution of hydro generation for thermal. The PV of the net benefits evaluated as of 2016 (expressed in terms of the 2016 price level) amounts to USD 529 billion Table 11.

Table 11 shows the distribution of the results by region regarding rates of return and PVs expressed in 2016 USD prices. The highest rates of return are realized in South Asia and East Asia, and the Pacific. The five dams constructed in South Asia, representing about $2.3 \mathrm{GW}$ of installed capacity, have produced an economic net benefit of about USD 50 billion for the region. The ex-post economic internal rate of return (EIRR) for the region is $21 \%$, falling slightly below the rate of return at the time of the appraisal, which is estimated to be $21.7 \%$. The 16 dams constructed in East Asia and the Pacific, representing about 7.1 GW of installed capacity, have produced an economic net benefit of about USD 100 billion for the region. The ex-ante EIRR for the region is $18.5 \%$, and the ex-post EIRR is $17.0 \%$.

The 16 dams built in Latin America and the Caribbean represent about $10.3 \mathrm{GW}$ of installed capacity. The $17 \%$ ex-ante EIRR estimated for the region turns out to be $13.7 \%$ ex-post. The deviation between the ex-ante and ex-post EIRR for the region is explained by the high magnitude of real cost overruns. Notwithstanding the high level of overruns, the dam investments have contributed an overall net economic gain of USD 232 billion to the region.

A total of USD 89 billion worth of net gains are expected to be realized in Sub-Saharan Africa by the end of the operating life cycle of the 12 dams built in the region. For this sub-sample, the ex-ante EIRR is estimated at $16.1 \%$, and the ex-post EIRR is $15.1 \%$.

The lowest rates of return are realized in Europe and Central Asia. Eight dams built in the region represent about $3.1 \mathrm{GW}$ of installed capacity and have produced an economic net benefit of about USD 57 billion for the region. The ex-ante EIRR is estimated at $13.7 \%$ for this region, but the ex-post results show that the projects' actual EIRR is $13.5 \%$ on average.

Table 11 column 9 shows how many dams in each region have actual negative NPVs. The highest number of negative NPV dams is in Latin America and the Caribbean, where half of the dams have negative NPVs. This could be explained by the high magnitude of real cost overruns in the region. This region is followed by South Asia and Sub-Saharan Africa, where $40 \%$ and $16.7 \%$ of the dams, respectively, have negative NPVs (Table 11, column 9). In Europe and Central Asia and East Asia and the Pacific, $12.5 \%$ of the dams have negative NPVs.

The PVs of the net benefits are reported in Table 12, column 6, by size (installed capacity) and type (with or without storage) of dams. The results show that the dams' internal rates of return (columns 7 and 8) increase with the size of generating capacity of the dam. Larger dams produce the bulk of the benefits and have relatively higher return rates on their investment outlays. Smaller dams have lower return rates, and the highest number of negative NPV projects is among these smaller dams. Some $36.8 \%$ of the smallest dams with 0-99 MW of installed capacity, 30\% of medium-sized dams with 300-699 MW of installed capacity, and $22.2 \%$ of dams with 100-299 MW of installed capacity have actual negative NPVs. That is not the case with the large-scale dams, where only one in ten have an actual negative NPV.

When it comes to dam types, there seems to be no significant difference in rates of return according to whether or not a dam has storage. There is a considerable difference in rates of return in large dams of 700-1499 MW of installed capacity. However, the number of dams with storage and without storage in this installed capacity range is not comparable. Therefore, this case is ignored.Concerning the relevance of hydropower in renewable energy targets, the SCC emissions avoided by hydropower dams are an indispensable part of this analysis. Adding this global benefit to the results increases the ex-ante EIRR for host countries in the portfolio from $17.4 \%$ to $19.5 \%$, and ex-post EIRR from $15.4 \%$ to $17.3 \%$ (Table 13). 
Table 12. Estimated vs. actual EIRR according to size of installed capacity (MW).

\begin{tabular}{|c|c|c|c|c|c|c|c|c|c|}
\hline $\begin{array}{l}\text { Size: Installed } \\
\text { Capacity (MW) }\end{array}$ & $\begin{array}{c}\text { Number of } \\
\text { Dams }\end{array}$ & $\begin{array}{l}\text { Total Capacity } \\
\text { Installed (MW) }\end{array}$ & $\begin{array}{l}\text { PV of Estimated } \\
\text { Costs @ 10\% (USD } \\
\text { Million, 2016) }\end{array}$ & $\begin{array}{l}\text { PV of Actual Costs } \\
@ 10 \% \text { (USD } \\
\text { Million, 2016) }\end{array}$ & $\begin{array}{l}\text { PV of Benefits @ } \\
10 \% \text { (USD } \\
\text { Million, 2016) }\end{array}$ & $\begin{array}{l}\text { Net PV of Hydro } \\
\text { @ 10\% (USD } \\
\text { Million, 2016) }\end{array}$ & $\begin{array}{c}\text { Ex-ante EIRR } \\
(\%)\end{array}$ & $\begin{array}{c}\text { Ex-post EIRR } \\
(\%)\end{array}$ & $\begin{array}{c}\text { Number of Dams } \\
\text { with Actual } \\
\text { Negative NPV }\end{array}$ \\
\hline & [1] & [2] & [3] & [4] & [5] & [6] & [7] & [8] & [9] \\
\hline $0-99$ & 19 & 969 & 64,532 & 76,498 & 83,008 & 6510 & 14.0 & 13.4 & 7 \\
\hline WS & 9 & 404 & 28,923 & 34,253 & 31,769 & -2484 & 14.0 & 12.9 & 5 \\
\hline WOS & 10 & 565 & 35,609 & 42,245 & 51,239 & 8994 & 14.0 & 13.8 & 2 \\
\hline $100-299$ & 18 & 3239 & 134,990 & 158,825 & 253,075 & 94,250 & 15.4 & 13.1 & 4 \\
\hline WS & 10 & 1801 & 89,223 & 103,051 & 167,329 & 64,279 & 15.6 & 14.0 & 1 \\
\hline WOS & 8 & 1438 & 45,768 & 55,774 & 85,745 & 29,971 & 15.1 & 12.0 & 3 \\
\hline WS & 9 & 3694 & 150,070 & 190,921 & 256,964 & 66,043 & 15.4 & 15.6 & 3 \\
\hline WOS & 1 & 412 & 961 & 1107 & 1868 & 760 & 16.2 & 14.7 & 0 \\
\hline $700-1499$ & 6 & 6450 & 116,257 & 180,786 & 284,964 & 104,177 & 19.5 & 17.0 & 1 \\
\hline WS & 5 & 5000 & 103,519 & 168,365 & 220,096 & 51,731 & 17.5 & 14.1 & 1 \\
\hline WOS & 1 & 1450 & 12,738 & 12,421 & 64,867 & 52,446 & 26.4 & 26.7 & 0 \\
\hline 1500 and above & 4 & 9642 & 239,516 & 343,980 & 601,641 & 257,661 & 17.8 & 15.3 & 0 \\
\hline WS & 4 & 9642 & 239,516 & 343,980 & 601,641 & 257,661 & 17.8 & 15.3 & 0 \\
\hline WOS & 0 & 0 & 0 & 0 & 0 & 0 & 0.0 & 0.0 & 0 \\
\hline Total & 57 & 24,405 & 706,327 & 952,118 & $1,481,519$ & 529,401 & 17.4 & 15.4 & 15 \\
\hline
\end{tabular}

Notes: WS, with storage; WOS, without storage.

Table 13. Estimated vs. actual EIRR according to region, with and without SCC.

\begin{tabular}{|c|c|c|c|c|c|c|c|c|c|c|c|c|}
\hline Region & $\begin{array}{l}\text { Number } \\
\text { of Dams }\end{array}$ & $\begin{array}{l}\text { Total Capacity } \\
\text { Installed } \\
\text { (MW) }\end{array}$ & $\begin{array}{l}\text { Avoided } \mathrm{CO}_{2} \\
\text { (Thousand } \mathrm{t} \text { ) }\end{array}$ & $\begin{array}{l}\text { PV of Actual } \\
\text { Costs @ 10\% } \\
\text { (USD Million, } \\
\text { 2016) }\end{array}$ & $\begin{array}{c}\text { PV of Benefits } \\
@ 10 \% \text { with } \\
\text { Avoided } \mathrm{CO}_{2} \\
\text { (USD Million, } \\
\text { 2016) }\end{array}$ & $\begin{array}{c}\text { Net PV of } \\
\text { Hydro @ 10\% } \\
\text { (USD Million, } \\
\text { 2016) }\end{array}$ & $\begin{array}{c}\text { Net PV of } \\
\text { Avoided } \mathrm{CO}_{2} \\
@ \text { 10\% (USD } \\
\text { Million, 2016) }\end{array}$ & $\begin{array}{c}\text { Net PV of } \\
\text { Hydro @ 10\% } \\
\text { with Avoided } \\
\mathrm{CO}_{2} \text { (USD } \\
\text { Million, 2016) }\end{array}$ & $\begin{array}{c}\text { Ex-ante EIRR } \\
\text { with Avoided } \\
\mathrm{CO}_{2} \\
(\%)\end{array}$ & $\begin{array}{c}\text { Ex-post EIRR } \\
\text { with Avoided } \\
\mathrm{CO}_{2} \\
(\%)\end{array}$ & $\begin{array}{c}\text { Difference in } \\
\text { Ex-Ante EIRR } \\
(\%)\end{array}$ & $\begin{array}{c}\text { Difference in } \\
\text { Ex-Ante EIRR } \\
(\%)\end{array}$ \\
\hline & [1] & [2] & [3] & [4] & [5] & [6] & [7] & [8] & [9] & [10] & [11] & [12] \\
\hline $\begin{array}{l}\text { East Asia and } \\
\text { Pacific }\end{array}$ & 16 & 7139 & 367,372 & 137,123 & 292,544 & 100,218 & 55,203 & 155,422 & 20.9 & 19.3 & 2.5 & 2.3 \\
\hline $\begin{array}{c}\text { Europe and Central } \\
\text { Asia }\end{array}$ & 8 & 3106 & 136,021 & 113,472 & 219,816 & 57,449 & 48,895 & 106,344 & 15.9 & 15.6 & 2.2 & 2.2 \\
\hline $\begin{array}{l}\text { Latin America and } \\
\text { Caribbean }\end{array}$ & 16 & 10,283 & 386,464 & 553,300 & 971,084 & 232,142 & 185,642 & 417,785 & 19.1 & 15.5 & 2.1 & 1.8 \\
\hline Total & 57 & 24,405 & $1,069,082$ & 952,118 & $1,823,732$ & 529,401 & 342,213 & 871,615 & 19.5 & 17.3 & 2.1 & 1.9 \\
\hline
\end{tabular}


For the sample of 57 dams, there is, on average, a $2.1 \%$ difference between ex-ante EIRRs calculated including and those calculated excluding the benefit of the avoided social cost of carbon emission Table 13. There is, on average, a 1.9\% difference between ex-post EIRRs calculated including and those calculated excluding the benefit of the avoided social cost of carbon emission. The PV of the net benefits evaluated as of 2016 (expressed in terms of the 2016 price level) increases from USD 529 billion with the addition of USD 342 billion of benefits of avoided carbon emissions, making the PV of net benefits USD 871 billion (Table 13, columns 6-8).

Table 13 shows that 16 dams in Latin America and the Caribbean avoid 386 million tonnes of carbon dioxide emissions throughout the lives of the projects; 16 dams in East Asia and the Pacific avoid 367 million tonnes of carbon dioxide emissions throughout the project lives. Eight dams in Europe and Central Asia, five in South Asia, and twelve in Sub-Saharan Africa avoid 136 million tonnes, 105 million tonnes, and 75 million tonnes of carbon dioxide emissions, respectively, throughout their project lives.

These estimates of reductions in GHG emissions have not taken the carbon emissions by the dam reservoirs into consideration. The role of dam reservoirs as carbon sinks or sources is highly reservoir-specific [52]. Information is not available to make this adjustment for each of the hydro dams. However, according to the International Hydro Association (2020) [53], the global medium GHG estimate of the emission intensity of the hydropower reservoirs was $18.5 \mathrm{gCO}_{2} \mathrm{eq} / \mathrm{kwh}$. This is the grams of carbon dioxide equivalent per kilowatt-hour of electricity generated over the dams' life cycle. Applying this rate of carbon source to the total generation of entire portfolio hydro dams, it would reduce the net carbon savings of the hydro dams by $7.22 \%$. The estimated total amount of $\mathrm{CO}_{2}$ saved by this portfolio of hydro dams is 1069 million tons, with this adjustment, the estimated amount of carbon saved would fall to 992 million tons. This adjustment has only a marginal impact on the overall economic rate of return of the portfolio of projects.

Figure 3 summarizes the number of dams in various regions with cost and time overruns. Figure $3 a$ shows the number of dams with cost overrun; Figure $3 b$ shows the number of dams with actual negative NPV in different regions with a cost overrun; Figure $3 c$ shows the number of dams with time overrun; Figure $3 \mathrm{~d}$ shows the number of dams with actual negative NPV in various regions with a time overrun.

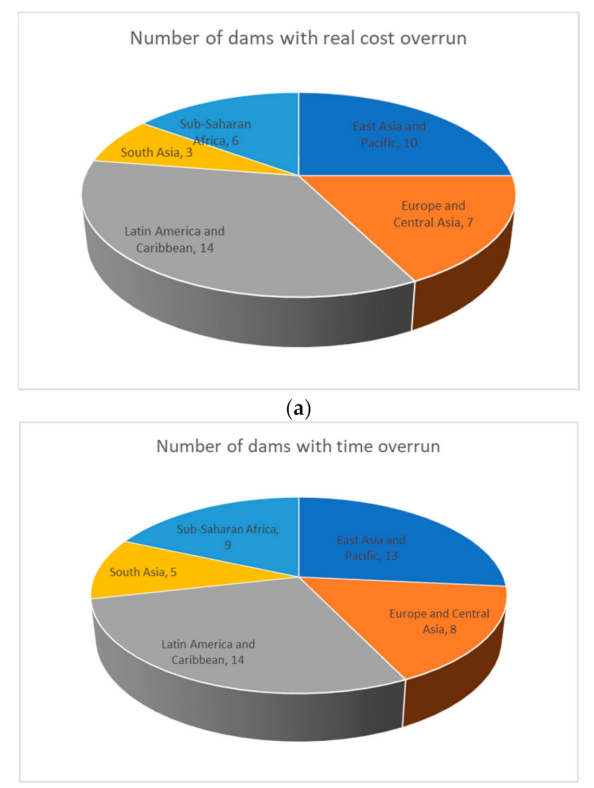

(c)

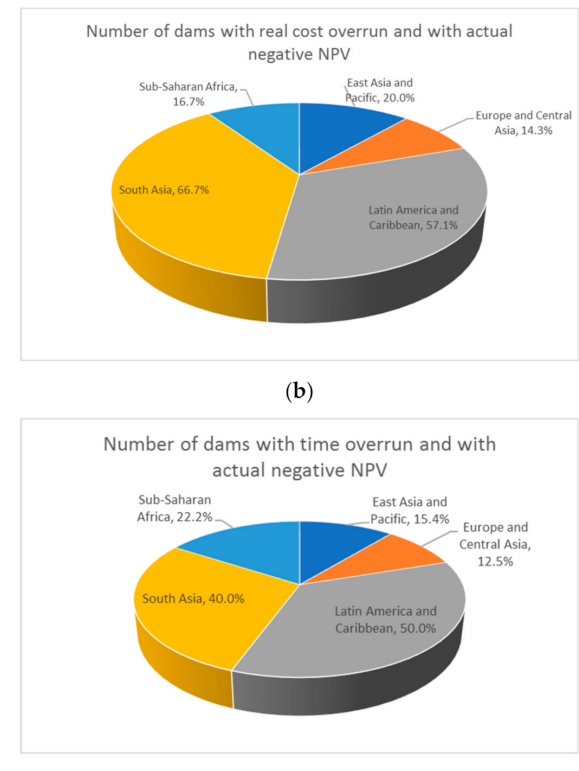

(d)

Figure 3. Projects with cost and time overruns across various regions: (a) Number of dams with real cost overrun; (b) Number of dams with real cost overrun and with actual negative NPV; (c) Number of dams with time overrun; (d) Number of dams with real cost overrun and with actual negative NPV. 
Of the total 40 dams with a real cost overrun (Figure 3a), 14 dams had a negative NPV. The region with the highest number of negative NPV dams is South Asia where out of three dams with cost overrun two have had an actual negative NPV. This has been followed by the Latin America and Caribbean region where 57.1\% of dams with cost overrun have had an actual negative NPV (Figure 3b) which could be attributable to high real cost overruns occurred in the region.

Of the total 49 dams with time overrun (Figure 3c), 14 dams had a negative NPV. 50\% of the dams with time overrun located in Latin America and the Caribbean have had an actual negative NPV which was followed by the South Asia region where $40 \%$ of dams with time overrun have had an actual negative NPV (Figure 3d).

\section{Conclusions and Policy Implications}

Although there is plenty of evidence to show that the construction costs and time schedules for the completion of hydropower dams are often underestimated at the initial stage of project appraisal, this study's findings support the view that hydropower dam investments are, on the whole, economically worthwhile. For the portfolio of 57 dams in this study, we find that about $70 \%$ of the dams incurred construction costs greater than their initial estimates. The weighted average real cost overrun is calculated as $31.4 \%$ of the estimated real cost for this dams' sample.

The cost of time overrun is measured as the cost of supplying power by alternative means during the delays in completing hydropower dams. More than $77 \%$ of the projects in this sample experienced a time overrun of more than $10 \%$ of the initial time estimated to complete the dams. The overall net cost of the time overrun is calculated as $11.1 \%$ of the dams' estimated real construction costs.

The magnitude of failure in cost estimations has not prevented most of these dams from being economically worthwhile investments. The dam investments have contributed a total net economic gain of USD 529 billion to the societies where they were built. For the 57 dams in this study, the average ex-ante and ex-post rates of return, excluding the benefits of avoided carbon emissions, are estimated at $17.4 \%$ and $15.4 \%$, respectively.

The ex-ante rate of return increases from $17.4 \%$ to $19.5 \%$ and ex-post from $15.4 \%$ to $17.3 \%$ when we add the benefits of avoided carbon emissions by the hydropower dams to the results. The PV of the net benefits evaluated as of 2016 increases from USD 529 billion by the addition of USD 342 billion of benefits of avoided carbon emissions, making the PV of net benefits USD 871 billion. This value of net benefits represents a significant contribution both to the well-being of the countries in which these dams are located (USD 529 billion) and to the rest of the world through their role in reducing carbon emissions (USD 342 billion).

These findings provide a strong empirical case for dam investments. The economic cost of generating and supplying an equivalent amount of electricity to these societies if these dams had not been constructed would have been much higher than the actual cost of hydropower dam projects. It is the costs of the dams and their benefits that need to be brought into the assessment when evaluating hydropower dam investments.

Author Contributions: Conceptualization, G.P.J.; methodology, G.P.J.; formal analysis, S.B. and G.O.O.-W.; investigation, S.B. and G.O.O.-W.; writing-original draft preparation, S.B.; writingreview and editing, S.B., G.P.J. and G.O.O.-W. All authors have read and agreed to the published version of the manuscript.

Funding: This research received no external funding.

Informed Consent Statement: Not applicable.

Data Availability Statement: The World Bank made available to the authors the ex-ante and ex-post appraisal reports, which provide detailed information on each dam. These documents are available at https://documents.worldbank.org/en/publication/documents-reports accessed on 8 April 2021. 
Acknowledgments: The assistance of Nouraddine Berrah, Migara Jayawardena, Sergio RiveraZeballos, and Omotola Awojobi are greatly appreciated. The research project from which this paper has evolved was funded by the Independent Evaluation Group of the WBG. The authors are solely responsible for all views reflected, all conclusions reached, and any errors in this study. Neither the WBG nor any of its staff is responsible for any of the views expressed or the conclusions reached in this paper.

Conflicts of Interest: The authors declare no conflict of interest.

$\begin{array}{ll}\text { Abbreviations } \\ \text { Btu } & \text { British thermal unit } \\ \text { CCGT } & \text { Combined-cycle gas turbine } \\ \mathrm{CO}_{2} \mathrm{e} & \text { Carbon emissions } \\ \text { EIRR } & \text { Economic internal rate of return } \\ \text { GW } & \text { Gigawatt } \\ \text { HFO } & \text { Heavy fuel oil } \\ \text { ICR } & \text { Implementation and Completion Reports } \\ \text { MRC } & \text { Marginal running cost } \\ \text { MW } & \text { Megawatt } \\ \text { NG } & \text { Natural gas } \\ \text { NPV } & \text { Net present value } \\ \text { O\&M } & \text { Operating and maintenance } \\ \text { OCGT } & \text { Open-cycle gas turbine } \\ \text { PAD } & \text { Project appraisal documents } \\ \text { PV } & \text { Present value } \\ \text { SCC } & \text { Social cost of carbon } \\ \text { WBG } & \text { World Bank Group } \\ \text { WOS } & \text { Withouth storage } \\ \text { WS } & \text { With storage }\end{array}$

\section{References}

1. International Energy Agency (IEA). World Energy Outlook; International Energy Agency (IEA): Paris, France, 2012.

2. Intralawan, A.; Wood, D.; Frankel, R.; Costanza, R.; Kubiszewski, I. Tradeoff analysis between electricity generation and ecosystem services in the Lower Mekong Basin. Ecosyst. Serv. 2018, 30, 27-35. [CrossRef]

3. Intralawan, A.; Smajgl, A.; McConnell, W.; Ahlquist, D.B.; Ward, J.; Kramer, D.B. Reviewing benefits and costs of hydropower development evidence from the Lower Mekong River Basin. Wiley Interdiscip. Rev. Water 2019, 6, e1347. [CrossRef]

4. Kummu, M.; Sarkkula, J. Impact of the Mekong River flow alteration on the Tonle Sap flood pulse. AMBIO J. Hum. Environ. 2008, 37, 185-192. [CrossRef]

5. Orr, S.; Pittock, J.; Chapagain, A.; Dumaresq, D. Dams on the Mekong River: Lost fish protein and the implications for land and water resources. Glob. Environ. Chang. 2012, 22, 925-932. [CrossRef]

6. Pittock, J.; Dumaresq, D.; Bassi, A.M. Modeling the hydropower-Food nexus in large river basins: A Mekong case study. Water 2016, 8, 425. [CrossRef]

7. Winemiller, K.O.; McIntyre, P.B.; Castello, L.; Fluet-Chouinard, E.; Giarrizzo, T.; Nam, S.; Sáenz, L. Balancing hydropower and biodiversity in the Amazon, Congo, and Mekong. Science 2016, 351, 128-129. [CrossRef]

8. Merrow, E.; Shangraw, R., Jr. Understanding the Costs and Schedules of World Bank Supported Hydroelectric Projects; World Bank Energy Series Paper No. 31; The World Bank: Washington, DC, USA, 1990.

9. Bacon, R.W.; Besant-Jones, J.E. Estimating construction costs and schedules: Experience with power generation projects in developing countries. Energy Policy 1998, 26, 317-333. [CrossRef]

10. Ansar, A.; Flyvbjerg, B.; Budzier, A.; Lunn, D. Should we build more large dams? The actual costs of hydropower megaproject development. Energy Policy 2014, 69, 43-56. [CrossRef]

11. Sovacool, B.; Nugent, D.; Gilbert, A. Construction cost overruns and electricity infrastructure: An unavoidable risk? Electr. J. 2014, 27, 112-120. [CrossRef]

12. Awojobi, O.; Jenkins, G.P. Were the hydro dams financed by the World Bank from 1976 to 2005 worthwhile? Energy Policy 2015, 86, 222-232. [CrossRef]

13. Braeckman, J.P.; Disselhoff, T.; Kirchherr, J. Cost and schedule overruns in large hydropower dams: An assessment of projects completed since 2000. Int. J. Water Res. Dev. 2019. [CrossRef]

14. Shaktawat, A.; Vadhera, S. Risk management of hydropower projects for sustainable development: A review. Environ. Dev. Sustain. 2020, 1-32. [CrossRef] 
15. Kentel, E.; Alp, E. Hydropower in Turkey: Economical, social and environmental aspects and legal challenges. Environ. Sci. Policy 2013, 31, 34-43. [CrossRef]

16. Dursun, B.; Gokcol, C. The role of hydroelectric power and contribution of small hydropower plants for sustainable development in Turkey. Renew. Energy 2011, 36, 1227-1235. [CrossRef]

17. Tahseen, S.; Karney, B.W. Reviewing and critiquing published approaches to the sustainability assessment of hydropower. Renew. Sustain. Energy Rev. 2017, 67, 225-234. [CrossRef]

18. Jamasb, T.; Nillesen, P.; Pollitt, M. Strategic behaviour under regulatory benchmarking. Energy Econ. 2004, 26, 825-843. [CrossRef]

19. Briones-Hidrovo, A.; Uche, J.; Martínez-Gracia, A. Determining the net environmental performance of hydropower: A new methodological approach by combining life cycle and ecosystem services assessment. Sci. Total Environ. 2020, $712,136369$. [CrossRef] [PubMed]

20. Atilgan, B.; Azapagic, A. Renewable electricity in Turkey: Life cycle environmental impacts. Renew. Energy 2016, 89, 649-657. [CrossRef]

21. Verán-Leigh, D.; Vázquez-Rowe, I. Life cycle assessment of run-of-river hydropower plants in the Peruvian Andes: A policy support perspective. Int. J. Life Cycle Assess. 2019, 24, 1376-1395. [CrossRef]

22. Li, Z.; Lu, L.; Lv, P.; Du, H.; Guo, J.; He, X.; Ma, J. Carbon footprints of pre-impoundment clearance on reservoir flooded area in China's large hydro-projects: Implications for GHG emissions reduction in the hydropower industry. J. Clean. Prod. 2017, 168, 1413-1424. [CrossRef]

23. Zhang, S.; Pang, B.; Zhang, Z. Carbon footprint analysis of two different types of hydropower schemes: Comparing earth-rockfill dams and concrete gravity dams using hybrid life cycle assessment. J. Clean. Prod. 2015, 103, 854-862. [CrossRef]

24. Barros, N.; Cole, J.J.; Tranvik, L.J.; Prairie, Y.T.; Bastviken, D.; Huszar, V.L.; Roland, F. Carbon emission from hydroelectric reservoirs linked to reservoir age and latitude. Nat. Geosci. 2011, 4, 593-596. [CrossRef]

25. Fanaian, S.; Graas, S.; Jiang, Y.; van der Zaag, P. An ecological economic assessment of flow regimes in a hydropower dominated river basin: The case of the lower Zambezi River, Mozambique. Sci. Total Environ. 2015, 505, 464-473. [CrossRef]

26. Liu, Y.; Ye, L.; Benoit, I.; Liu, X.; Cheng, Y.; Morel, G.; Fu, C. Economic performance evaluation method for hydroelectric generating units. Energy Convers. Manag. 2003, 44, 797-808. [CrossRef]

27. Yildiz, V.; Vrugt, J.A. A toolbox for the optimal design of run-of-river hydropower plants. Environ. Model. Softw. 2019, 111, 134-152. [CrossRef]

28. Motwani, K.H.; Jain, S.V.; Patel, R.N. Cost analysis of pump as turbine for pico hydropower plants-A case study. Procedia Eng. 2013, 51, 721-726. [CrossRef]

29. Aslan, Y.; Arslan, O.; Yasar, C. A sensitivity analysis for the design of small-scale hydropower plant: Kayabogazi case study. Renew. Energy 2008, 33, 791-801. [CrossRef]

30. Karlis, A.D.; Papadopoulos, D.P. A systematic assessment of the technical feasibility and economic viability of small hydroelectric system installations. Renew. Energy 2000, 20, 253-262. [CrossRef]

31. Santolin, A.; Cavazzini, G.; Pavesi, G.; Ardizzon, G.; Rossetti, A. Techno-economical method for the capacity sizing of a small hydropower plant. Energy Convers. Manag. 2011, 52, 2533-2541. [CrossRef]

32. Nouni, M.R.; Mullick, S.C.; Kandpal, T.C. Techno-economics of micro-hydro projects for decentralized power supply in India. Energy Policy 2006, 34, 1161-1174. [CrossRef]

33. Liebenthal, A. The World Bank's Experience with Large Dams: A Preliminary Review of Impacts; Master Plan; The World Bank: Washington, DC, USA; Japan International Cooperation Agency: Tokyo, Japan, 1997; p. 200.

34. Head, C. Financing of Private Hydropower Projects; The World Bank: Washington, DC, USA, 2000.

35. Jenkins, G.; Zuker, R. Blue Gold: Hydro-Electric Rent in Canada (No. 1984-01); JDI Executive Programs; Canadian Govt. Pub. Centre: Ottawa, ON, Canada, 1984.

36. Dhakal, D.N.S.; Jenkins, G.P. Risk sharing in hydropower development: Case study of the Chukha Hydel Project in Bhutan. Water Policy 2013, 15, 109-125. [CrossRef]

37. World Bank Operations Evaluation Department (OED). The World Bank's Experience of Large Dams: A Preliminary Review of Impacts; The World Bank: Washington, DC, USA, 1996.

38. Asmal, K. Dams and Development: A New Framework for Decision-Making; The Report of the World Commission on Dams; Earthscan: Abingdon-on-Thames, UK, 2000.

39. Hutchinson, J.; Inwood, S.; James, R.; Ramachandran, G.; Hamel, J.; Libby, C. Program on Technology Innovation: Integrated Generation Technology Options (1019539); Electric Power Research Institute: Palo Alto, CA, USA, 2009; pp. 1-112.

40. Seifi, H.; Sepasian, M.S. Electric Power System Planning: Issues, Algorithms and Solutions; Springer Science \& Business Media: Berlin/Heidelberg, Germany, 2011.

41. Cantarelli, C.C.; Flyvbjerg, B.; Buhl, S.L. Geographical variation in project cost performance: The Netherlands versus worldwide. J. Transport. Geogr. 2012, 24, 324-331. [CrossRef]

42. Cantarelli, C.C.; Van Wee, B.; Molin, E.J.; Flyvbjerg, B. Different cost performance: Different determinants? The case of cost overruns in Dutch transport infrastructure projects. Transport. Policy 2012, 22, 88-95. [CrossRef]

43. Drummond, J. The Origins of the 'S-curve' in Business Functions. Available online: http:/ / www.businessfunctions.com/articles / The $\% 20$ Origins $\% 20$ of $\% 20$ the $\% 20$ S\%20Curve $\% 20$ in $\% 20$ Business $\% 20$ Functions.pdf (accessed on 11 November 2013). 
44. Energy Information Administration (EIA). Capital Cost Estimates for Utility Scale Electricity Generating Plants; Energy Information Administration (EIA): Washington, DC, USA, 2016.

45. Environmental Protection Agency (EPA). Inventory of U.S. Greenhouse Gas Emissions and Sinks: 1990-2013; Environmental Protection Agency (EPA): Washington, DC, USA, 2015.

46. Lazard. Levelized Cost of Energy Analysis-Version 9.0; 2015. Available online: https://www.lazard.com/media/2390/lazardslevelized-cost-of-energy-analysis-90.pdf (accessed on 2 April 2018).

47. Ray, D. Lazard's Levelized Cost of Energy Analysis—Version 13.0; Lazard: New York, NY, USA, 2019.

48. EIA. U.S. Energy Information Administration (EIA). 2020. Available online: https://www.eia.gov/outlooks/steo/realprices/ (accessed on 5 April 2018).

49. International Energy Agency (IEA). Energy Prices and Taxes, 2nd Quarter 2014; International Energy Agency (IEA): Paris, France, 2014; p. 9.

50. Interagency Working Group (IWG). Technical Support Document: Technical Update of the Social Cost of Carbon for Regulatory Impact Analysis; Under Executive Order 12866; The Interagency Working Group on the Social Cost of Greenhouse Gases: Washington, DC, USA, 2016.

51. Bacon, R.W.; Besant-Jones, J.E.; Heidarian, J. Estimating Construction Costs and Schedules. Experience with Power Generation Projects in Developing Countries; World Bank Technical Paper No. 325; The World Bank: Washington, DC, USA, 1996.

52. Phyoe, W.W.; Wang, F. A review of carbon sink or source effect on artificial reservoirs. Int. J. Environ. Sci. Technol. 2019, 16, 2161-2174. [CrossRef]

53. International Hydropower Association. Hydropower Status Report, Sector Trends, and Insights. 2018. Available online: https:/ / www.hydropower.org/factsheets/greenhouse-gas-emissions (accessed on 8 April 2021). 